CHAPTER 12

\title{
Maximus the Confessor's View on Soul and Body in the Context of Five Divisions
}

\author{
Vladimir Cvetković
}

\begin{abstract}
The aim of this paper is to analyse how Maximus the Confessor understands the unity between the body and soul, and how he fits this unity in the general framework of the fivefold divisions or distinctions that exist in the world.
\end{abstract}

\section{Introduction}

Maximus the Confessor is one of a very few Greek Fathers who explicitly argued about predetermined Incarnation. In Maximus' interpretation from $\mathrm{Ad}$ Thalassium, the Holy Trinity created the world with the vision of the final unity between divine and human. ${ }^{1}$ This vision also included the appearance of the Logos of God in the body and his adoption of human nature, ${ }^{2}$ as the archetype according to which this unity will be modelled. If the world is created with the foreknowledge of divine Incarnation and the final creaturely deification, then one may argue that the fashioning of the world has also comprised some unities of the lesser kind as the precondition for the final unity of divine and human. Maximus' doctrine of the fivefold division that exists in the nature from his Ambiguum 41, points to lesser unities, i.e. unities between male and female, paradise and the inhabited world, earth and sky and sensible and intelligible nature as necessary steps towards the final unity between human and divine. Since the unity between the divine and human nature is usually interpreted by Maximus and other post-Chalcedonian authors by analogy with the human body and soul, I argue in this paper that the body-soul union in the human being is created as the perfect example of how two different natures

1 Maximus Confessor, Questiones ad Thalassium (=qu. Thal.) 6o.4, in:_C. Laga / C. Steel (eds.), Maximi Confessoris Quaestiones ad Thalassium 2: Quaestiones LVI-LXV, CChr.SG 22, Turnhout 1990.

2 Max., qu. Thal. 6o.7. 